\title{
Changes in latitudes, changes in aptitudes: Nucella canaliculata (Mollusca: Gastropoda) is more stressed at its range edge
}

\author{
Cascade J. B. Sorte, Gretchen E. Hofmann* \\ Department of Ecology, Evolution, and Marine Biology, and the Marine Science Institute, University of California, \\ Santa Barbara, California 93106, USA
}

\begin{abstract}
A paradigm in biogeography is that organisms have 'abundant center' distributions, with abundances peaking at the range center and declining towards the range boundaries. One explanation for this pattern is that abundances are associated with organisms' physiological stress levels and performances, with organisms experiencing more stress at the range edges. Here we explored whether the intertidal dogwhelk Nucella canaliculata was distributed in an 'abundant center' pattern. We addressed the role of stress in setting the species' range limits. We determined dogwhelk abundances at range-center and range-edge sites and measured physiological stress levels by quantifying the $70 \mathrm{kDa}$ heat-shock protein as a biochemical stress index. N. canaliculata was less abundant and more stressed at its southern range edge than at the range center, suggesting that populations at the range edge may be most impacted by global climate change.
\end{abstract}

KEY WORDS: Nucella canaliculata $\cdot$ Biogeography $\cdot$ Species range $\cdot$ Biomarkers $\cdot$ Hsp70

Resale or republication not permitted without written consent of the publisher

\section{INTRODUCTION}

Environmental gradients often correlate with species' biogeographic ranges. For example, plant densities are related to moisture and elevation gradients (see Brown 1984), blue mussel Mytlius edulis biomass declines with decreasing salinity in the Baltic Sea (Westerbom et al. 2002), and sea snail Liparis liparis abundances are correlated with seawater temperature at their southern range edge (Henderson \& Seaby 1999). However, the causal link between environmental factors, physiological performance, and organisms' geographical range limits remains obscure.

A prevailing paradigm in biogeography, the 'abundant center hypothesis' (ACH), associates species' distributions with environmental effects on organismal performance and fitness (for a review, see Sagarin \& Gaines 2002a). The ACH states that a species' abundance peaks at the center of its range and declines towards its range boundaries. Organisms' abundances and fitness levels are predicted to peak in the species' range center, at an environmental optimum, and decline towards its range edges as environmental conditions become more unfavorable (Menge \& Sutherland 1987, Huey 1991). It follows that range boundaries occur where organisms lack suitable habitat, such as where the severity of environmental conditions exceeds organisms' physiological tolerances. Several studies support the $\mathrm{ACH}$, as well as its physiological basis (for a review, see Brown 1984). However, underlying the hypothesis is the unproven assumption that organisms are more stressed at species' range boundaries.

In addition, despite its paradigm status, the prevalence of the $\mathrm{ACH}$ has recently been called into question. Sagarin \& Gaines (2002a) reviewed 22 empirical studies of the $\mathrm{ACH}$ and found that it was supported in only $39 \%$ of their tests. Similarly, Blackburn et al. 


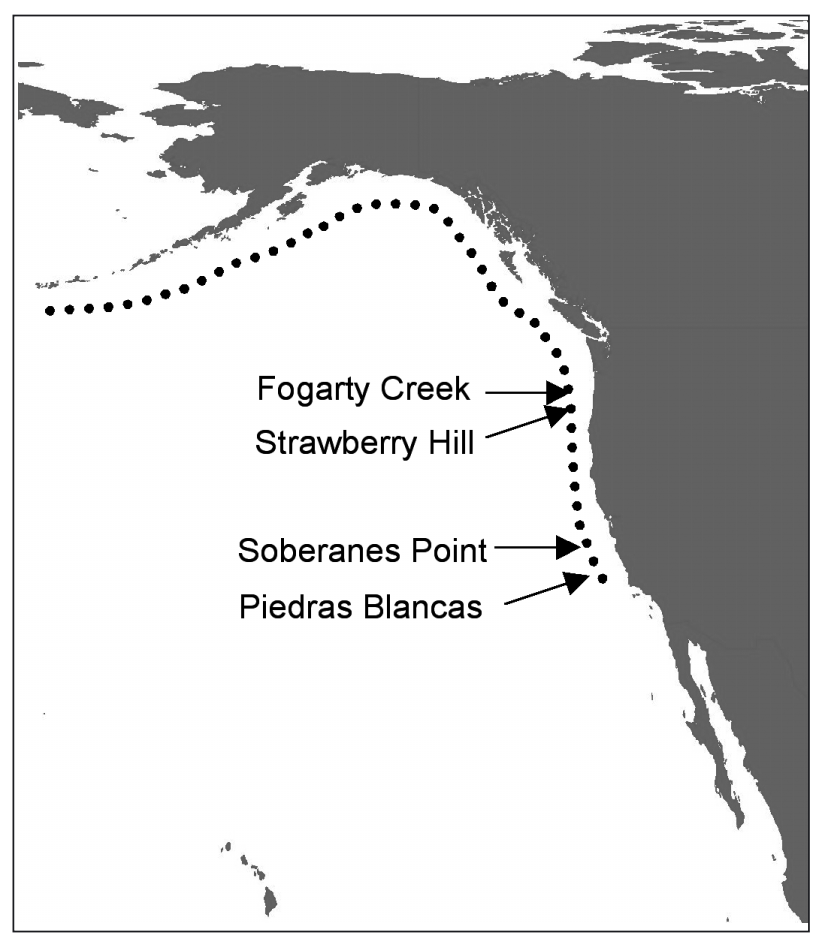

Fig. 1. Locations of field sites for collection of Nucella canaliculata on the northeastern Pacific coast. Range-center sites were Fogarty Creek and Strawberry Hill, Oregon, and rangeedge sites were Soberanes Point and Piedras Blancas, California. The dotted line represents the latitudinal distribution of N. canaliculata (Collins et al. 1996, Sorte 2003)

(1999) analyzed Common Birds Census distribution data of passerine bird species in Great Britain and observed no significant relationship between 32 species' densities and the distance from range edges. Sagarin \& Gaines (2002b) surveyed the latitudinal abundance distributions of 12 intertidal invertebrates. Depending on the analysis used, only 1 or 2 of the invertebrate species showed 'abundant center' distributions (a 'normal' curve when a species' abundance is plotted against latitude), whereas 5 or 6 of the species were most abundant at one or both range edges. Thus, although numerous ecological hypotheses are based on the assumption that the $\mathrm{ACH}$ is a biogeographical rule (Sagarin \& Gaines 2002a), further research is needed to determine the prevalence and underlying mechanism of the hypothesis.

The aim of the present study was to test the ACH and the prediction that species are more physiologically stressed at their range boundaries. We investigated the abundances and stress levels of the intertidal dogwhelk Nucella canaliculata at its range edge and range center. Specifically, we asked (1) does $N$. canaliculata display an 'abundant center' distribution? If so, (2) are abundances and physiological stress levels correlated so that $N$. canaliculata individuals are more stressed at the species' range edge? The answers to these questions not only provide insights into the mechanisms underlying species' distributions, but also provide clues about biogeographic effects of global climate change.

\section{MATERIALS AND METHODS}

Study species. The study species was the intertidal dogwhelk Nucella canaliculata. Intertidal organisms are ideal for biogeographical studies because (1) their geographic distributions are essentially 1-dimensional, leading to 2 well-defined (north and south) range boundaries, and (2) they experience temporally predictable bouts of environmental stress (e.g. temperature and desiccation) associated with emersion during the tidal cycle. N. canaliculata ranges from the Aleutian Islands, Alaska south to Piedras Blancas, California, USA (Fig. 1) (Collins et al. 1996, Sorte 2003). Unlike the 2 local congeners $(N$. emarginata and $N$. ostrina), which are isomorphic where their ranges overlap, N. canaliculata can be identified to species in the field.

Field observations. Individuals of Nucella canaliculata were counted and collected at 4 field sites; 2 sites each at the center and edge of the species' latitudinal range (Fig. 1). The range-center sites sampled were Fogarty Creek (FC; $44^{\circ} 50^{\prime} \mathrm{N}, 124^{\circ} 03^{\prime} \mathrm{W}$ ) and Strawberry Hill ( $\left.\mathrm{SH} 44^{\circ} 15^{\prime} \mathrm{N}, 127^{\circ} 07^{\prime} \mathrm{W}\right)$, located approximately $70 \mathrm{~km}$ apart on the central Oregon coast. The range-edge sites were Soberanes Point (SP; $35^{\circ} 40^{\prime} \mathrm{N}$, $\left.121^{\circ} 17^{\prime} \mathrm{W}\right)$ and Piedras Blancas $\left(\mathrm{PB}_{;} 35^{\circ} 40^{\prime} \mathrm{N}\right.$, $\left.121^{\circ} 17^{\prime} \mathrm{W}\right)$, spaced approximately $170 \mathrm{~km}$ apart on the south-central California coast.

We attempted to minimize the effects of regional differences in tidal regime by our choice of field sampling dates. Dogwhelk abundance counts and collections were performed at the range-edge sites in mid-April 2003 (18 April at PB and 19 April at SP) and at the range-center sites in mid-May 2003 (16 May at SH and 17 May at FC). At the time of collection, both regions were in the middle of periods of negative tides, and low tides occurred between 06:00 and 08:00 $\mathrm{h}$ at all sites. Inevitably, there were some regional differences in conditions. Tidal magnitude was greater at the Oregon sites $(\sim 3.5 \mathrm{~m})$ as compared to the California sites $(\sim 2.5 \mathrm{~m})$. Predicted emersion time (without accounting for the influence of waves) was longer at the California sites. However, greater significant wave heights in California (approximately 3 and $1 \mathrm{~m}$ in California and Oregon, respectively; NOAA buoy data) likely narrowed this difference in emersion times.

Abundances of Nucella canaliculata were determined by timed counts (Ausden 1996, Geiger \& Daane 
2001, Yoo et al. 2003). At the range-center sites, 3 replicate counts were performed, each starting from a different location at a $1.3 \mathrm{~m}$ tide height (above MLLW), by 2 individuals over a period of $3 \mathrm{~min}$ at FC and $1 \mathrm{~min}$ at $\mathrm{SH}$. At the range-edge sites, dogwhelks were counted for an average of 59 min by 2 individuals, and $46 \mathrm{~min}$ by 3 individuals, at $\mathrm{SP}$ and $\mathrm{PB}$, respectively. Within that period, replicate counts began from each of 3 locations (1.3 $\mathrm{m}$ tide height) at $\mathrm{SP}$, whereas single counts began from random starting locations at $\mathrm{PB}$.

Sample collection and immunological methods. We assessed physiological stress levels by measuring concentrations of a molecular stress biomarker: heatshock protein 70 (Hsp70). Hsps are molecular chaperones, which assist in the folding of new proteins and the refolding of stress-denatured cellular proteins (for reviews, see Lindquist 1986, Fink 1999, Hartl \& HayerHartl 2002). The particular Hsp that we quantified, Hsp70, is a stress-induced member of the $70 \mathrm{kDa}$ Hsp gene family, and its cellular concentration increases directly with the organism's stress 'load' (Hofmann \& Somero 1995, Feder \& Hofmann 1999, Dahlhoff 2004).

Nucella canaliculata were collected approximately $1.3 \mathrm{~m}$ above MLLW, especially at the range-center sites where high dogwhelk abundances made such tideheight specificity possible. Dogwhelks were flashfrozen and transported on dry ice. They were stored at $-70^{\circ} \mathrm{C}$ prior to analysis.

In the laboratory, samples of foot tissue were dissected and homogenized. Foot tissue was used because it is metabolically active and easy to isolate from surrounding tissues and food items. Hsp70 levels in the resulting supernatants were determined by gel electrophoresis and western blotting (Hofmann \& Somero 1995, Halpin et al. 2002, C. J. B. Sorte \& G. E. Hofmann unpubl.). For immunodetection of Hsp70, the primary antibody used was an anti-Hsp70 rabbit polyclonal antibody (StressGen; SPA-812), and the secondary antibody was a goat anti-rabbit IgG $(\mathrm{H}+\mathrm{L})$ horseradish peroxidase conjugate (Bio-Rad; 170-6515). SuperSignal chemiluminescent substrate (Pierce), a Versadoc Imaging System (Bio-Rad), and Quantity One software (BioRad) were used for detection and densitometric analysis of the Hsp70 bands. A supernatant was prepared from heat-shocked mussel (Mytilus californianus) gill tissue, and $5 \mu \mathrm{l}$ of mussel supernatant were loaded on each gel as a standard and positive control. All Hsp70 levels are reported relative to the Hsp70 present in this heat-shocked mussel standard.

Data analysis. The SAS System for Windows v. 8 (SAS Institute) was employed for all nested analyses of variance (ANOVA), with sites nested within regions (range edge or range center), using general linear models. We confirmed that the ANOVA assumptions of normality and homogeneity of variance were met by visually examining residual plots. Only the dogwhelk abundance data needed to be log transformed $(\ln [x+1])$ to meet these assumptions. For the abundance data, the counts of 2 individual observers starting from 3 locations were treated as replicates, resulting in $\mathrm{n}=6$ replicates per site. The exception was $\mathrm{PB}$, where each of 3 individuals performed a single timed count (over roughly a $1 \mathrm{~h}$ period) for $\mathrm{n}=3$ replicates. All data are expressed as mean \pm standard error, and statistical significance was accepted at $\mathrm{p}<0.05$.

\section{RESULTS}

Nucella canaliculata were 35 times more abundant in the center of their range than at their range edge $\left(F_{1,8}=860.53, \mathrm{p}<0.0001\right.$; Fig. 2$)$, after accounting for site differences. The statistical model explained $99.2 \%$ of the variance in abundances. In addition, there were significant differences between sites $\left(F_{2,8}=55.98, \mathrm{p}<\right.$ 0.0001). Dogwhelk abundances at the range center were 4 times higher at $\mathrm{SH}$ than at FC and, at the range edge, were slightly higher at PB than at SP.

Physiological stress levels were inversely related to dogwhelk abundances. Levels of Hsp70 were higher in dogwhelks collected at the range-edge sites as compared to those from the range-center sites $\left(F_{1,52}=8.24\right.$, $p=0.0059$; Fig. 3). There were no within-region site effects on levels of Hsp70 ( $p>0.25)$.

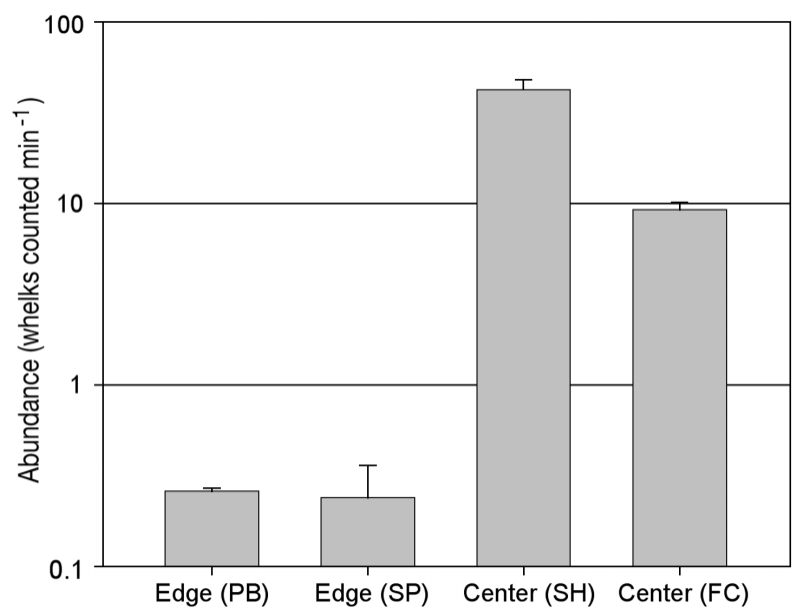

Fig. 2. Nucella canaliculata. Abundances at range-edge (PB: Piedras Blancas; SP: Soberanes Point) and range-center (SH: Strawberry Hill; FC: Fogarty Creek) sites. Dogwhelk abundances are plotted on a logarithmic scale and were determined at a tide height of $1.34 \mathrm{~m}$ by timed counts performed in April (range-edge sites) and May 2003 (range-center sites). Data are means $( \pm 1 \mathrm{SE})$ of 6 replicate counts (made by 2 observers starting from 3 locations), except at PB where counts by 3 observers, each starting from a random location, were used as replicates. Dogwhelk abundances were higher at the range-center sites than at the range-edge sites $(p<0.0001)$ 


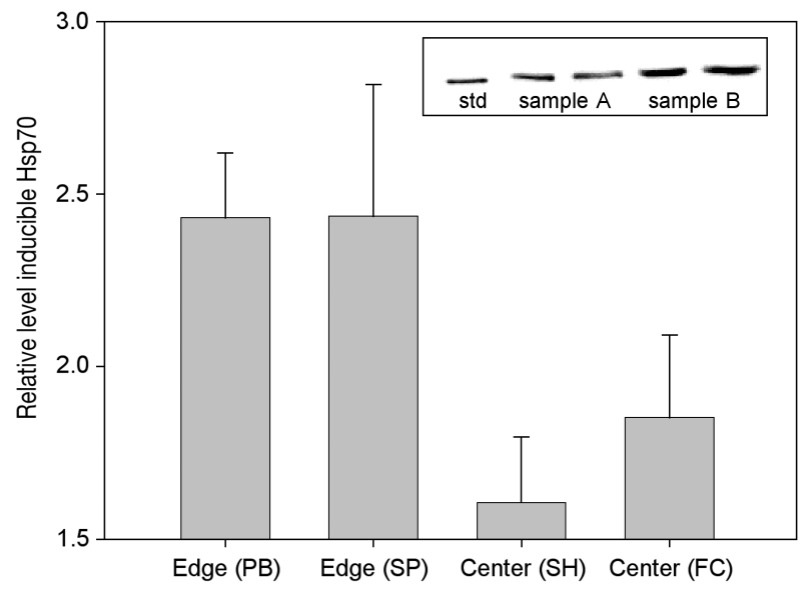

Fig. 3. Nucella canaliculata. Inducible Hsp70 levels. Hsp70 levels were determined in foot tissue and are relative to $5 \mu \mathrm{l}$ of a heat-shocked mussel standard. Hsp70 levels were higher in dogwhelks collected at the range-edge sites, as compared to those from the range-center sites $(p=0.0059)$. Each bar represents the mean $( \pm 1 \mathrm{SE})$ of $n=15$ dogwhelks (except at $\mathrm{SP}$ for which $n=11$ dogwhelks). Inset: representative Hsp70 western blot. The heat-shocked mussel standard (std) was run on each gel, and dogwhelk samples were run in duplicate. PB: Piedras Blancas; SP: Soberanes Point; SH: Strawberry Hill; FC: Fogarty Creek

\section{DISCUSSION}

The ACH predicts that organisms' abundances peak in the species' range center and decrease towards the species' range boundaries. As predicted by the $\mathrm{ACH}$, timed counts of Nucella canaliculata indicate that dogwhelk abundances were higher at the range center and lower at the southern range edge. A larger-scale census of over 40 locations spanning our study sites showed that abundances of $N$. canaliculata peaked in central and southern Oregon and declined further south (P. Raimondi \& C. Blanchette unpubl. data). Even with our limited number of field sites, it would seem that abundance data from only 2 points can give insight into the factors determining a species' distribution (Caughley et al. 1988). Caughley et al. (1988) theorize, for example, that if abundances do not differ between range-center and range-edge locations, then possible edge-determining factors do not change in a gradient fashion (e.g. substrate availability). If, as seen for $N$. canaliculata, abundances are lower at the range edge than at the range center, Caughley et al. (1988) suggest that climate, resource availability, and biotic factors (e.g. predators, parasites, or pathogens) are possible causes.

Patterns of inducible Hsp70 expression indicate higher physiological stress levels in the range-edge dogwhelks as compared to the range-center dogwhelks. Myriad stressors induce Hsp70 production, including temperature, salinity, desiccation, anoxia, UV light, and trace metals (Sanders 1993, Feder \& Hofmann 1999). These multiple environmental stressors (e.g. temperature and desiccation) likely act synergistically and are thus simultaneously reflected in the dogwhelks' Hsp70 levels. Biotic factors may also modify the effects of environmental stress in biogeographic patterning. For example, while few studies have addressed the effects of nutrition on Hsp expression, prey availability directly affects an organism's fitness and performance. Wieters (1999) found a strong correlation between abundances of the congener $\mathrm{Nu}$ cella emarginata and local prey (mussel and barnacle) recruitment at multiple sites on the central California coast. Interestingly, in addition to indicating physiological stress levels, Hsp70 may also confer temperature tolerance in this and other dogwhelk species (C. J. B. Sorte \& G. E. Hofmann unpubl.).

Teasing apart the factors determining organisms' physiological stress levels involves choosing from a suite of environmental stress biomarkers, of which Hsps are one (Somero 2002, Dahlhoff 2004). Hsps are especially useful because individuals can be collected in the field and frozen until analysis, unlike measures requiring live organisms (e.g. cardiac function and respiration). Not only do Hsps build up in cells upon repeated stress events (e.g. leading to higher levels at the end of the summer; Hofmann \& Somero 1995), making them a time-integrated measure, but they can also be used to rapidly detect stress events as soon as $5 \mathrm{~h}$ following the event (Hofmann \& Somero 1996, Tomanek \& Somero 2000). Finally, Hsps are produced in response to protein-denaturing stresses from multiple sources and therefore represent an assimilation of total stress 'load' (Feder \& Hofmann 1999). The latter 2 advantages can also be disadvantages, due to the difficulty of determining the intensity, duration, and sources of the stresses. In order to develop a better picture of these aspects of the organisms' stress environments, multiple biomarkers can be employed. For example, Downs et al. (2000) created a system involving 10 biochemical indices (including several Hsps) in order to assess the response of coral Montastraea faveolata to heat stress. Similarly, Gracey et al. (2001) used DNA microarray techniques to generate a profile of thousands of gene transcripts of the goby Gillichthys mirabilis, produced in response to hypoxia.

This application of stress biomarkers is particularly timely because of the recent biogeographical focus on understanding the underpinnings of species' biogeographic ranges and predicting how species' distributions will be affected by global climate change (McCarty 2001, Warren et al. 2001, Parmesan \& Yohe 2003, Root et al. 2003, Zacherl et al. 2003). The use of biochemical indices can aid in the forecasting of cli- 
mate-related changes by increasing our understanding of (1) environmental stress levels over species' ranges, (2) the physiological stress levels of the local individuals, and (3) the effects of the physiological stress on the individuals' performances.

Based on the field sites censused in this study, Nucella canaliculata may display an abundant center distribution, and dogwhelk abundances were inversely related to physiological stress levels. It is possible, therefore, that range-edge abundances will decrease as global temperatures increase, leading to a range contraction at the southern range edge. Further study on additional species' abundance patterns and physiological stress levels could similarly aid in the identification of factors responsible for biogeographic ranges and abundances. The results of such studies can inform attempts to predict future changes in biogeographic patterning.

Acknowledgements. We thank M. Bracken, M. Foley, and P. Halpin for help with fieldwork. M. Bracken, K. Foltz, S. Gaines, B. Helmuth, S. Lester, and E. Sanford gave helpful comments on the research and manuscript, and members of the Lubchenco-Menge Lab (OSU) generously provided equipment and lab space. We acknowledge J. Bogacki and the Bureau of Land Management for providing access to the Piedras Blancas field site. This research was conducted under National Marine Sanctuary Permit MBNMS-2003-007. This study was supported by a Grant-in-Aid of Research from Sigma Xi, the Scientific Research Society to C.J.B.S., National Science Foundation grant IBN0097100 to G.E.H., and support from Susan and Bruce Worster to G.E.H. as the Worster Scholar at UCSB. This is contribution number 153 of the Partnership for Interdisciplinary Studies of Coastal Oceans (PISCO): A long-term ecological consortium funded by the David and Lucile Packard Foundation.

\section{LITERATURE CITED}

Ausden M (1996) Invertebrates. In: Sutherland WJ (ed) Ecological census techniques: a handbook. Cambridge University Press, Cambridge, p 145-147

Blackburn TM, Gaston KJ, Quinn RM, Gregory RD (1999) Do local abundances of British birds change with proximity to range edge? J Biogeogr 26:493-505

Brown JH (1984) On the relationship between abundance and distribution of species. Am Nat 124:255-279

Caughley G, Grice D, Barker R, Brown B (1988) The edge of the range. J Anim Ecol 57:771-785

Collins TM, Frazer K, Palmer AR, Vermeij GJ, Brown WM (1996) Evolutionary history of northern hemisphere Nucella (Gastropoda, Muricidae): molecular, morphological, ecological, and paleontological evidence. Evolution 50:2287-2304

Dahlhoff EP (2004) Biochemical indicators of stress and metabolism: applications for marine ecological studies. Annu Rev Physiol 66:06.01-06.25

Downs CA, Mueller E, Phillips S, Fauth JE, Woodley CM (2000) A molecular biomarker system for assessing the health of coral (Montrastraea faveolata) during heat stress. Mar Biotechnol 2:533-544
Feder ME, Hofmann GE (1999) Heat-shock proteins, molecular chaperones, and the stress response: evolutionary and ecological physiology. Annu Rev Physiol 61:243-282

Fink AL (1999) Chaperone-mediated protein folding. Physiol Rev 79:425-449

Geiger CA, Daane KM (2001) Seasonal movement and distribution of the grape mealybug (Homoptera: Pseudococcidae): developing a sampling program for San Joaquin Valley vineyards. J Econ Entomol 94:291-301

Gracey AY, Troll JV, Somero GN (2001) Hypoxia-induced gene expression profiling in the euryoxic fish Gillichthys mirabilis. Proc Natl Acad Sci USA 98:1993-1998

Halpin PM, Sorte CJ, Hofmann GE, Menge BA (2002) Patterns of variation in levels of Hsp70 in natural rocky shore populations from microscales to mesoscales. Integr Comp Biol 42:815-824

Hartl FU, Hayer-Hartl M (2002) Molecular chaperones in the cytosol: from nascent chain to folded protein. Science 295: 1852-1858

Henderson PA, Seaby RM (1999) Population stability of the sea snail at the southern edge of its range. J Fish Biol 54: 1161-1176

Hofmann GE, Somero GN (1995) Evidence for protein damage at environmental temperatures: seasonal changes in levels of ubiquitin conjugates and HSP70 in the intertidal mussel Mytilus trossulus. J Exp Biol 198: $1509-1518$

Hofmann GE, Somero GN (1996) Protein ubiquitination and stress protein synthesis in Mytilus trossulus occurs during recovery from tidal emersion. Mol Mar Biol Biotechnol 5: 175-184

Huey RB (1991) Physiological consequences of habitat selection. Am Nat 137:S91-S115

Lindquist S (1986) The heat-shock response. Annu Rev Biochem 55:1151-1191

McCarty JP (2001) Ecological consequences of recent climate change. Conserv Biol 15:320-331

Menge BA, Sutherland JP (1987) Community regulation: variation in disturbance, competition, and predation in relation to environmental stress and recruitment. Am Nat 130:730-757

Parmesan C, Yohe G (2003) A globally coherent fingerprint of climate change impacts across natural systems. Nature 421:37-42

Root TL, Price JT, Hall KR, Schneider SH, Rosenzweig C, Pounds JA (2003) Fingerprints of global warming on wild animals and plants. Nature 421:57-60

Sagarin RD, Gaines SD (2002a) The 'abundant centre' distribution: to what extent is it a biogeographical rule? Ecol Lett $5: 137-147$

Sagarin RD, Gaines SD (2002b) Geographical abundance distributions of coastal invertebrates: using one-dimensional ranges to test biogeographic hypotheses. J Biogeogr 29: 985-997

Sanders BM (1993) Stress proteins in aquatic organisms: an environmental perspective. Crit Rev Toxicol 23:49-75

Somero GN (2002) Thermal physiology and vertical zonation of intertidal animals: optima, limits, and cost of living. Integr Comp Biol 42:780-789

Sorte CJB (2003) The ecophysiological underpinnings of biogeographic patterns: temperature effects on the distributions of Nucella congeners. MA thesis, University of California, Santa Barbara, CA

Tomanek L, Somero GN (2000) Time course and magnitude of synthesis of heat-shock proteins in congeneric marine snails (genus Tegula) from different tidal heights. Physiol Biochem Zool 73:249-256 
Warren MS, Hill JK, Thomas JA, Asher J and 11 others (2001) Rapid responses of British butterflies to opposing forces of climate and habitat change. Nature 414:65-69

Westerbom M, Kilpi M, Mustonen O (2002) Blue mussels, Mytlius edulis, at the edge of the range: population structure, growth and biomass along a salinity gradient in the north-eastern Baltic Sea. Mar Biol 140:991-999

Wieters EA (1999) The consequences of variable recruitment of prey for predators. MS thesis, Moss Landing Marine

Editorial responsibility: John Lawrence (Contributing Editor), Tampa, Florida, USA
Laboratories, San Jose State University, San Jose, CA Yoo HJS, Stewart-Oaten A, Murdoch WW (2003) Converting visual census data into absolute abundance estimates: a method for calibrating timed counts of a sedentary insect population. Ecol Entomol 28:490-499

Zacherl D, Gaines SD, Lonhart SI (2003) The limits to biogeographical distributions: insights from the northward range extension of the marine snail, Kelletia kelletii (Forbes, 1852). J Biogeogr 30:913-924

Submitted: October 9, 2003; Accepted: April 10, 2004

Proofs received from author(s): June 8, 2004 